\title{
PENGARUH PROFITABILITAS, LEVERAGE DAN CORPORATE GOVERNANCE TERHADAP PERENCANAAN PAJAK PADA PERUSAHAAN MANUFAKTUR YANG TERDAFTAR DI BURSA EFEK INDONESIA TAHUN 2014-2017
}

\author{
Indah Rahmadini*1, Nita Erika Ariani ${ }^{* 2}$ \\ ${ }^{1,2}$ Program Studi Akuntansi Fakultas Ekonomi dan Bisnis Universitas Syiah Kuala \\ e-mail: indah.rahmadini96@ gmail.com ${ }^{* 1}$, nea@ unsyiah.ac.id ${ }^{* 2}$
}

\begin{abstract}
Abstrak
This study aims to examine the effect of profitability, leverage, and corporate governance on tax planning. The independent variables used in this study are profitability, leverage, institutional ownership, managerial ownership, independent commissioners and audit committees. While the dependent variable in this study is tax planning.Tax planning in this study the measured of Cash Effective Tax Rate (CETR). The population in this study are manufacturing companies listed on Indonesian Stock Exchange (BEI) in the period 2014-2017. Determination of samples in this study using purposive sampling method. There are 45 manufacturing companies listed on BEI used as research samples based on predetermined criteria. The results showed that profitability, leverage, managerial ownership, independent commissioners and audit committees had a significant effect on tax planning. Meanwhile institutional ownership has no significant effect on tax planning
\end{abstract}

Keywords: Tax Planning, Profitability, leverage, corporate governance

\section{Pendahuluan}

\section{Latar Belakang}

Pemerintah dalam menjalankan kegiatan pembangunan dan kegiatan pemerintahannya membutuhkan dana yang tidak sedikit. Dana itu sendiri dikumpulkan dari potensi-potensi sumber daya yang dimiliki oleh negara, baik itu hasil dari kekayaan alam maupun iuran dari masyarakat. Iuran masyarakat ini berbentuk pembayaran pajak yang menjadi dana utama yang dipergunakan oleh pemerintah dalam melakukan pembangunan yang sedang dilaksanakan ataupun yang akan dijalankan (Ferry \& Anna, 2013). Hampir 78 persen penerimaan yang diterima oleh negara berasal dari pajak. Tahun 2017 penerimaan perpajakan mencapai $\mathrm{Rp} 1.339,8$ triliun atau 88,4 persen dari total penerimaan negara. Penerimaan ini mencapai 91 persen dari target APBN Perubahan (APBN-P) tahun 2017, dimana target APBN-P itu sendiri sebesar Rp 1.450,9 triliun. Jumlah ini menjadi penerimaan perpajakan tertinggi dibandingkan dengan realisasi pada dua tahun sebelumnya yang berada di kisaran 88,3 persen dan 83,5 persen (https://ekonomi.kompas.com).
Untuk peningkatan penerimaan atas pajak tersebut pemerintah telah memperbaiki dan menyempurnakan peraturan perpajakan yang diterapkan di Indonesia. Perbaikan dan penyempurnaan ini diharapkan dapat menambah kesadaran wajib pajak untuk ikut berkontribusi dalam proses pembangunan negara dengan cara membayar pajak (Fatharani, 2012). Namun masalah dalam proses peningkatan penerimaan atas pajak ini adalah kesediaan wajib pajak dalam membayar pajak tersebut. Membayar pajak merupakan sebuah beban yang akan mengurangi penghasilan wajib pajak. Ini disebabkan karena besarnya jumlah pajak yang dibayarkan didasarkan kepada berapa tinggi jumlah laba ataupun penghasilan yang diperoleh oleh wajib pajak (Rori, 2013).

Wajib pajak tentunya selalu menginginkan penghasilan yang tinggi, namun penghasilan yang tinggi akan menimbulkan beban pajak yang besar sehingga mengurangi penghasilan. Selanjutnya jika beban pajak yang dibayarkan oleh wajib pajak besar, maka akan membuat perusahaan melakukan usaha untuk memperkecil jumlah pajak tersebut. Upaya memperkecil jumlah pajak yang dilakukan oleh wajib 
pajak ini dinamakan dengan perencaan pajak (tax planning) (Pohan, 2013: 8). Perencanaan pajak adalah sarana bagi wajib pajak untuk mematuhi kebijakan perpajakan namun jumlah pajak yang dibayarkan dapat diminimalisasikan sehingga tidak terlalu banyak mengurangi penghasilan yang didapatkan. Perencanaan pajak dapat dilakukan dengan cara memanfaatkan kelemahan-kelemahan yang ada dari peraturan pepajakan (loopholes) (Suandy, 2008: 8).

Strategi Perencanaan pajak yang sering dilakukan oleh perusahaan adalah memanfaatkan kelemahan dari peraturan yang ada. Strategi ini disebut dengan penghindaran pajak (tax avoidance) yang merupakan cara mengurangi jumlah pajak yang dibayarkan namun secara legal (Zain, 2008: 67).

Pada Tahun 2015 perusahaan Google masuk ke dalam daftar perusahaan yang terkena masalah dengan pajak sehingga tunggakan pajak Google mencapai Rp 5,5 triliun. Google terbukti melakukan perencanaan pajak di perusahaannya dengan memanfaatkan sistem perpajakan di Indonesia. Ada 2 cara yang dilakukan oleh Google untuk menghindari pajaknya. Cara pertama yaitu Google berusaha supaya tidak memiliki Bentuk Usaha Tetap (BUT) di Indonesia. BUT Google sendiri terletak di Singapura. Jika Google mempunyai BUT di Indonesia maka penghasilan mereka akan dikenakan tarif pajak, karena BUT merupakan salah satu syarat pemungutan pajak atas pajak penghasilan. Cara yang kedua, Google tidak membentuk BUT keagenannya di Indonesia sehingga seluruh kontaknya dengan konsumen Indonesia berlangsung secara online dan berhubungan langsung dengan Google Singapura. Ini menyebabkan Google menyangkal kalau memiliki BUT di Indonesia karena berdasarkan faktanya kontrak-kontrak yang terjadi tidak melalui kantor perwakilan di Indonesia (liputan6.com).

\section{Rumusan Masalah}

Berdasarkan uraian dari latar belakang di atas, maka rumusan masalah dalam penelitian ini adalah:

1. Apakah Profitabilitas berpengaruh terhadap perencanaan pajak pada perusahaan manufaktur yang terdapat di Bursa Efek Indonesia tahun 2014-2017

2. Apakah Leverage berpengaruh terhadap perencanaan pajak pada perusahaan manufaktur yang terdapat di Bursa Efek Indonesia tahun 2014-2017
3. Apakah kepemilikan institusional berpengaruh terhadap perencanaan pajak pada perusahaan manufaktur yang terdapat di Bursa Efek Indonesia tahun 2014-2017

4. Apakah kepemilikan manajerial berpengaruh terhadap perencanaan pajak pada perusahaan manufaktur yang terdaftar di Bursa Efek Indoesia tahun 2014-2017

5. Apakah komisaris independen berpengaruh terhadap perencanaan pajak pada perusahaan manufaktur yang terdaftar di Bursa Efek Indonesia tahun 2014-2017

6. Apakah komite audit berpengaruh terhadap perencanaan pajak pada perusahaan manufaktur yang terdaftar di Bursa Efek Indonesi tahun 20142017.

7. Apakah profitabilitas, leverage, kepemilikan institusional, kepemilikan manajerial, komisaris independen dan komite audit berpengaruh secara bersama-sama terhadap perencanaan pajak pada perusahaan manufaktur yang terdaftar di Bursa Efek Indonesi tahun 2014-2017

\section{Tujuan Penelitian}

Berdasarkan dari rumusan masalah tersebut, tujuan penelitian yang ingin dicapai dalam penelitian ini adalah:

1 Untuk menguji pengaruh Profitabilitas terhadap perencanaan pajak pada perusahaan manufaktur yang terdapat di Bursa Efek Indonesia tahun 2014-2017

2 Untuk menguji pengaruh Leverage terhadap perencanaan pajak pada perusahaan manufaktur yang terdapat di Bursa Efek Indonesia tahun 2014-2017

3 Untuk menguji pengaruh kepemilikan institutional terhadap perencanaan pajak pada perusahaan manufaktur yang terdaftar di Bursa Efek Indonesia tahun 2014-2017

4 Untuk menguji pengaruh kepemilikan manajerial terhadap perencanaan pajak pada perusahaan manufaktur yang terdapat di Bursa Efek Indonesia tahun 2014-2017

5 Untuk menguji pengaruh komisaris independen terhadap perencanaan pajak pada perusahaan manufaktur yang terdaftar di Bursa Efek Indonesia tahun 2014-2017 
6 Untuk menguji pengaruh komite audit terhadap perencanaan pajak pada perusahaan manufaktur yang terdaftar di Bursa Efek Indonesia tahun 2014-2017

7 Untuk menguji pengaruh profitabilitas, leverage, kepemilikan institusional, kepemilikan manajerial, komisaris independen dan komite audit terhadap perencanaan pajak pada perusahaan manufaktur yang terdaftar di Bursa Efek Indonesi tahun 2014-2017

\section{Kajian Pustaka}

\section{Agency Theory (Teori Keagenan)}

Teori keagenan merupakan teori yang menjelaskan hubungan antara pemilik kepentingan (principle) dengan manajer (agent) dalam mengelola perusahaan. Principle adalah suatu kelompok yang memiliki kepentingan dengan perusahaan dan mendelegasikan wewenang yang mereka punya kepada si agesnt yaitu manajemen. Jensen dan Mecling pada tahun 1996 menjelaskan bahwa teori agensi adalah teori yang membahas tentang hubungan antara principle ataupun pemilik saham yang mempunyai kepentingan terhadap perusahaan dengan agent atau manajemen yang bertugas untuk menjalankan perusahaan sesuai dengan kebutuhan pemlik saham tersebut.

Jansen dan Meckling mendeskripsikan akan ada dua masalah yang akan timbul pada teori keagenan, yaitu :

a. Moral hazard, yaitu masalah yang akan timbul jika agen melakukan tindakan yang tidak sesuai dengan kontrak yang telah disepakati sebelumnya.

b. Adverse selection, yaitu permasalahan yang timbul dimana prinsipal tidak mengetahui alasan pengambilan keputusan yang dilakukan oleh agen, apakah didasari oleh informasi yang handal atau karena adanya unsur kepentingan.

Adapun Hubungan antara teori agensi dengan perencanaan pajak dapat dilihat dari kepentingan perusahaan untuk mendapatkan laba dengan kewajiban atas pembayaran pajak yang akan dibayarkan atas laba tersebut. Permasalahnnya terjadi antara pemungut pajak yang disebut fiskus dengan manajemen perusahaan. Fiskus berharap jumlah pajak yang diterima akan besar, sementara dilain sisi manajemen berusaha untuk mengecilkan jumlah pajak yang dibayarkan walaupun pertumbuhan laba meningkat (Prakosa, 2014).

\section{Profitabilitas}

Rasio yang digunakan untuk menilai kemampuan perusahaan dalam mendapatkan keuntungan ini disebut dengan profitabilitas. Selain untuk mengukur kemampuan perusahaan untuk menghasilkan laba, rasio ini juga digunakan untuk melihat sejauh mana efektifnya kinerja manajemen perusahaan tersebut. Ini terlihat dari jumlah laba yang dihasilkan dari kegiatan perusahaan dan jumlah pendapatan dari kegiatan investai (Kasmir, 2014:196).

\section{Return On Total Asset (ROA)}

Return on total asset (ROA) adalah salah satu rasio dalam profitabilitas yang digunakan untuk mengukur tingkat kemampuan perusahaan dalam memperoleh keuntungannya dari keseluruhan aset yang dimiliki oleh persahaan tersebut (Hanafi dan Abdul Halim, 2009:84).

Menurut Harahap (2004:36) untuk menghitung ROA dapat menggunakan formula:

$$
\mathrm{ROA}=\frac{\text { Laba (Rugi) bersih sebelum pajak }}{\text { total aset }} \times 100 \%
$$

\section{Leverage}

Rasio ini digunakan perusahaan dalam mengukur penggunaan hutang untuk membiayai aset perusahan. Selain itu rasio ini diguanakan untuk mengukur seberapa mampu perusahaan membayar kewajiban ataupun hutang yang digunakan, baik itu berupa hutang jangka panjang ataupun jangka pendek jika nantinya perusahaan harus dilikuidasi (Fahmi,2010: 127).

\section{Debt to Equity Ratio}

Rasio ini merupakan rasio yang membandingkan jumlah hutang perusahaan dengan modal sendiri. Semakin tinggi nilai rasio ini, maka semakin banyak hutang yang digunakan oleh perusahaan untuk mengelola perusahaannya dan sedikit menggunakan modal sendiri. Baiknya perusahaan tidak menggunakan hutang terlalu tinggi di perusahaannya, dan dianjurkan bobotnya sama dengan modal sendiri (Munawir, 2010: 71). 
Rumus untuk DER :

$$
\text { DER }=\frac{\text { jumlah hutang }}{\text { modal sendiri }}
$$

\section{Mekanisme Corporate Governance}

CG adalah peraturan-peraturan yang menjelaskan hubungan antara pemilik kepentingan baik itu pemegang saham, pihak ketiga atau kreditur dimana hubungan ini bisa menjadi pemicu meningkatnya kinerja keuangan perusahaan. Meningkatnya kinerja keuangan perusahaan merupakan tujuan dari para pemangku kepentingan tersebut. Selain itu CG juga merupakan sarana bagi pemilik kepentingan untuk mengawasi kegiatan ataupun aktivitas yang dilakukan oleh manajer supaya sesuai dengan tujuan dan harapan pemilik kepentingan, serta untuk meningkatkan tranparasi pada perusahaan tersebut (Taufik \& Yulius, 2017).

Proksi yang digunakan peneliti untuk menghitung corporate governance adalah kepemilikan institusional, kepemilikan mnajerial, komisaris independent, dan komite audit .

\section{Kepemilikan Institusional}

Kepemilikan institusional merupakan jumlah saham yang dimiliki oleh institusi dan blockholders pada akir pencatatan. Institusi disini dapat berupa perusahaan penginvestasi, perusahaan dibidang asuransi, ataupun lembaga yang memiliki karakteristik sama dengan perusahaan yang telah disebutkan. Sedangkan blockholders merupakan individu atau perorangan yang memiliki jumlah saham diatas 5\% dimana individu tersebut bukan termasuk kedalam kategori kepemilikan manajerial (Sulistiani, 2013).

Rumus untuk kepemilikan institusional:

$$
\text { Kepemilikan Institutional }=\frac{\text { Jumlah saham hak institusi }}{\text { Jumlah saham beredar }} \times 100 \%
$$

\section{Kepemilikan Manajerial}

Kepemilikan manajerial adalah jumlah saham perusahaan yang dimiliki oleh manajemen dimana manajemen ikut serta dalam pengambilan keputusan pada suatu perusahaan yang bersangkutan (Agustiani, 2013). Menurut Sabila (2012) kepemilikan manajerial diukur dengan persentase jumlah saham yang dimiliki oleh pihak manajemen dari seluruh modal saham perusahaan yang beredar. Pengukuran ini dapat dirumuskan sebagai berikut:
Kepemilikan Manajerial $=\frac{\text { Jumlah saham pihak manajemen }}{\text { Jumlah saham beredar }} \times 100 \%$

\section{Komisaris Independen}

Dalam pedoman umum good corporate governance (2006:13) pengertian komisaris independen adalah anggota dewan komisaris yang tidak terafilliasi dengan direksi, anggota dewan komisaris lainnya dan pemegang saham pengendali, serta bebas dari hubungan bisnis atau hubungan lainnya yang dapat mempengaruhi kemampuannya untuk bertindak independen atau bertindak sematamata untuk kepentingan perseroan.

Menurut Meria dan Nur (2013), proporsi kepemilikan independen dapat diukur berdasarkan presentase jumlah dewan komisaris independen terhadap jumlah total dewan komisaris yang ada. Pengukuran ini dapat dirumuskan sebagai berikut:

Kepemilikan Institutional $=\frac{\text { Jumlah komisaris independen }}{\text { Jumlah anggota dewan komisaris yang ada }} \times 100 \%$

\section{Komite Audit}

Peraturan Ikatan Komite Audit yang dikutip oleh Effendi (2009:25), menjelaskan komite audit adalah suatu komite yang bekerja secara profesional dan independen yang dibentuk oleh dewan komisaris dan dengan demikian, tugasnya adalah membantu dan memperkuat fungsi dewan komisaris (atau dewan pengawas) dalam menjalankan fungsi pengawasan (oversight) atas proses pelaporan keuangan, manajemen risiko, pelaksanaan audit dan implementasi dari corporate governance di perusahaan-perusahaan.

Komite audit dapat diukur dengan rumus berikut :

$$
\sum \text { jumlah komite audit }
$$

\section{Perencanaan pajak}

Menurut Zain (2008: 67) perencanaan pajak merupakan proses tindakan untuk menyusun dan merencakan setiap transaksi yang akan dilakukan oleh perusahaan sehingga transaksi tersebut hanya dikenakan tarif pajak yang minimal. Pemilihan transaksi diharapkan akan hanya menimbulkan utang pajak yang sedikit baik itu pajak penghasilan ataupun pajak lainnya.

Perencanaan pajak itu sendiri terdiri dari dua strategi. Pertama penghindaran pajak (Tax Avoidance) 
yang merupakan perbuatan meminimalkan pajak secara legal yang masih dalam ruang lingkup peraturan perundang-undangan perpajakan. Kedua penyeludupan pajak (Tax Evasion) yang merupakan tindakan pelanggaran peraturan perpajakan dan ini illegal atau tidak diperbolehkan oleh pemerintah (Suandy, 2011:8).

\section{Penghindaran Pajak (Tax Avoidance)}

Penghindran pajak (Tax avoidance) merupakan kegiatan pengaturan untuk menentukan transaksi yang akan dijalankan oleh perusahaan sehingga dapat mengurangi atau menghilangkan beban pajak beserta berapa besar pajak yang dikenakan atas transaksi tersebut.

\section{Definisi Cash ETR}

Pengukuran penghindaran pajak dalam penelitian ini menggunakan formula dari Dyreng, et. al, (2010) yaitu Cash Effective Tax Rate (CETR). CETR merupakan formula yang membandingkan antara beban pajak yang dibayarkan dengan laba sebelum beban pajak.

Semakin kecil nilai CETR , artinya semakin besar penghindaran pajaknya, begitupun sebaliknya. Adapun rumus CETR itu sendiri adalah :

$$
\mathrm{CETR}=\frac{\text { Cash Tax Paid }}{\text { Pre Tax Income }}
$$

\section{Hipotesis Penelitian}

Hipotesis yang diajukan dalam penelitian ini adalah sebagai berikut:

H1: Profitabilitas berpengaruh terhadap perencanaan pajak.

$\mathrm{H} 2$ : Leverage berpengaruh terhadap perencanaan pajak.

H3: Kepemilikan institusional berpengaruh terhadap perencanaan pajak.

H4: Komisaris independen berpengaruh terhadap perencanaan pajak.

H5: Kepemilikan manajerial berpengaruh terhadap perencanaan pajak.

H6: Komite audit berpengaruh terhadap perencanaan pajak.

H7 : Pengaruh Profitabilitas, Leverage, Kepemilikan Institusional, Kepemelikan Manajerial, Komisaris Independen dan Komite Audit terhadap Perencanaan Pajak

\section{Metode Penelitian Desain Penelitian}

Desain penelitian merupakan kerangka kerja yang dapat memudahkan peniliti dalam melakukan penelitiannya dikarenakan semua yang akan dilakukan telah terencana berdasarkan urutan penelitiannya. Suatu karya ilmiah akan memberikan hasil yang memuaskan apabila dalam penelitiannya menggunakan metode dan teknik tertentu agar data yang diperoleh memenuhi syarat antara lain faktual, objektif, dan relevan.

\section{Populasi dan Sampel Penelitian}

Populasi merupakan suatu keseluruhan yang dijadikan subjek penelitian dan dipakai untuk menggeneralisasi hasil penelitian (Arikunto, 2013). Populasi dalam penelitian ini yaitu perusahaan manufaktur yang terdaftar di BEI pada periode tahun 2014-2017 yang berjumlah 142 dari 3 sektor perusahaan manufaktur.

\section{Sumber dan Teknik Pengumpulan Data}

Berdasarkan sumbernya, data dalam penelitian ini adalah data yang didapat dari pengaksesan situs BEI atau disebut dengan data eksternal. Begitu juga dengan teknik pengumpulan data yang dilakukan dalam penelitian ini adalah teknik pengumpulan eksternal dimana laporan tahunan yang digunakan didownload pada situs resmi BEI yaitu web.idx.id.

\section{Metode Analisis}

Penelitian ini menggunakan regresi linier berganda sebagai model dalam analisanya. Penelitian ini juga menggunakan uji asumsi klasik dimana menggunakan uji normalitas, ji ultikolinieritas, uji autokorelasi dan uji heteroskedastisitas. Untuk menguji hipotesis yang telah dirumuskan, penelitian ini menggunakan koefisien determinasi, uji statistik F, dan uji statistik T. Analisis ini digunakan untuk menguji seberapajauh dan bagaimana arah dari variable independen mempengaruhi variabel dependen. Model persamaan regresi tersebut sebagai berikut:

$$
\mathrm{Y}=\alpha+\beta 1 \mathrm{X} 1+\beta 2 \mathrm{X} 2+\beta 3 \mathrm{X} 3+\beta 4 \mathrm{X} 4+
$$
$\beta 5 \times 5+\beta 6 \times 6+\beta 7 \times 7+e$

Keterangan:

$$
\begin{array}{ll}
\mathrm{Y} & =\text { Perencanaan Pajak } \\
\mathrm{A} & =\text { Konstanta }
\end{array}
$$




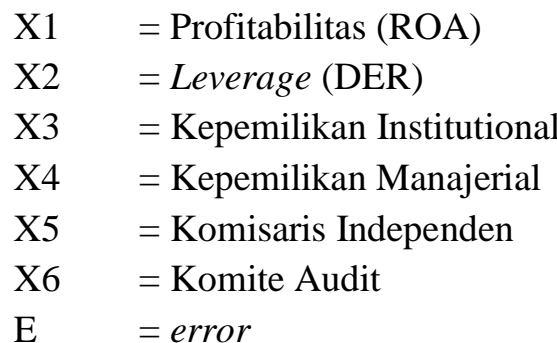

$\mathrm{X} 1=$ Profitabilitas $(\mathrm{ROA})$

$\mathrm{X} 3=$ Kepemilikan Institutional

X4 = Kepemilikan Manajerial

X5 $=$ Komisaris Independen

$\mathrm{E} \quad=$ error

Berdasarkan hasil uji asumsi klasik, maka analisis regresi linear berganda dapat dilakukan pada penelitian ini.Analisis regresi linear diperlukan guna mengetahui koefisien-koefisien regresi serta signifikansi sehingga dapat dipergunakan untuk menjawab hipotesis. Adapun hasil analisis regresi berganda dapat dilihat pada tabel 4.2 berikut:

\section{Hasil Penelitian}

\section{Analisi Regresi Linear Berganda}

Tabel 4.2

Hasil Regresi Linear Berganda

\section{Coefficients $^{\mathrm{a}}$}

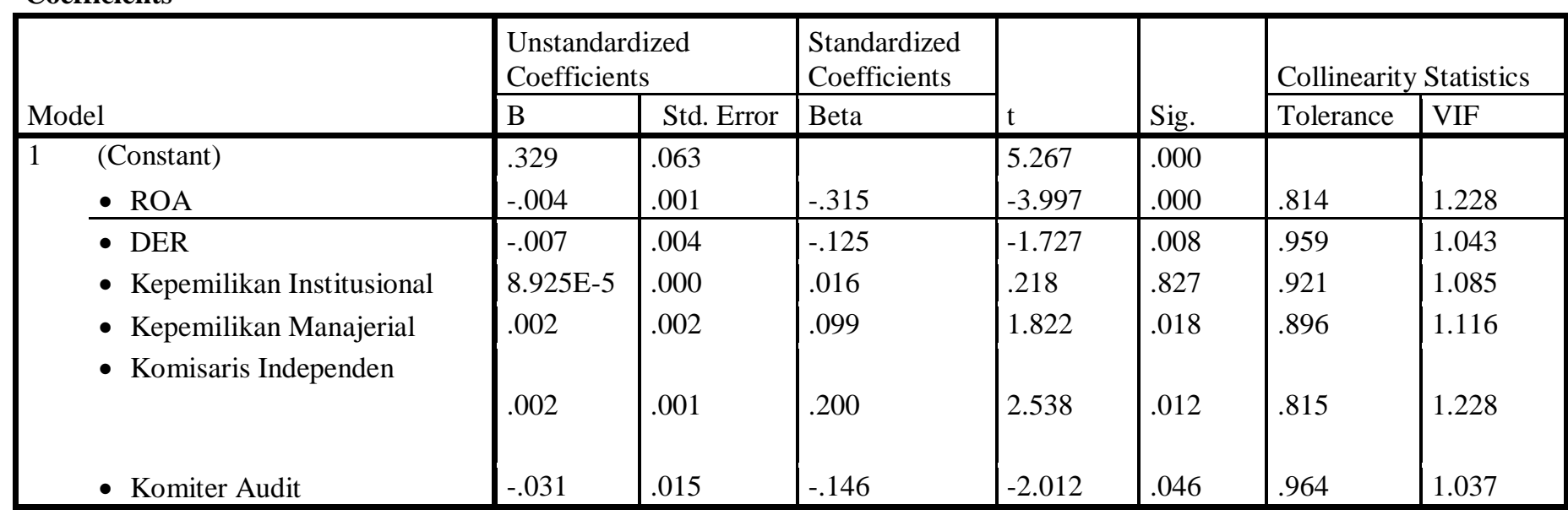

a. Dependent Variable: CETR

Sumber : Data yang diolah (2018)

Berdasarkan tabel di atas dapat diketahui persamaan regresi adalah sebagai berikut:

$\mathrm{Y}=\alpha+\beta 1 \mathrm{X} 1+\beta 2 \mathrm{X} 2+\beta 3 \mathrm{X} 3+\beta 4 \mathrm{Xs} 4+\beta 5 \mathrm{X} 5+$ $\beta 6 \times 6+\beta 7 \times 7+\mathrm{e}$

CETR $=32.9-0.004 \mathrm{X} 1-0,007 \mathrm{X} 2+8.93 \mathrm{X} 3+$ $0,002 \mathrm{X} 4+0,002 \mathrm{X} 5-0.031 \mathrm{X} 6+\mathrm{e}$

Persamaan tersebut menunjukkan bahwa nilai konstanta sebesar 5,267 mempunyai arti bahwa jika semua variabel independen (profitabilitas, leverage, kepemilikan institusional, kepemilikan manajerial, komisaris independen dan komite audit), konstan, maka menyebabkan nilai dari perencanaan pajak adalah sebesar $32,9 \%$.

\section{Uji Asumsi Klasik \\ Uji Normalitas}

Pengujian normalitas yang dilakukan dalam penelitian ini dapat dilihat pada gambar 4.1 dan gambar 4.2 berikut:

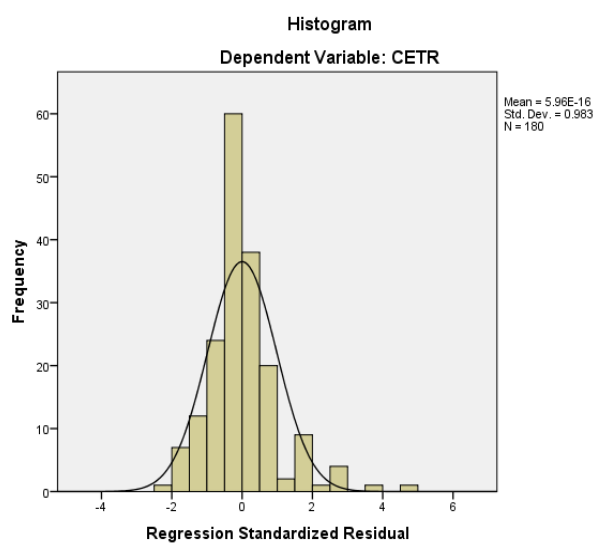

Sumber : Data diolah (2018)

\section{Gambar 4.1 Hasil Uji Normalitas dengan Histogram Normal}

Pada gambar 4.1 di atas dapat dilihat bahwa residual terdistribusi secara normal dan berbentuk simetris, tidak melenceng ke kanan ataupun ke kiri.Artinya data yang digunakan dalam penelitian ini baik karena mempunyai pola seperti lonceng (bell 
sheped) dan ini berarti data yang digunakan mendekati distribusi normal.

\section{Uji Multikolinearitas}

Uji multikolinearitas bertujuan untuk menguji apakah model regresi ditemukan adanya korelasi antar variabel independen.Model regresi yang baik seharusnya tidak terjadi korelasi antar variabel independen.

Berikut hasil uji Multikolinearitas yang dapat dilihat dalam Tabel 4.3.

Tabel 4.3

Hasil Uji Multikolinearitas

Coefficients $^{\mathrm{a}}$

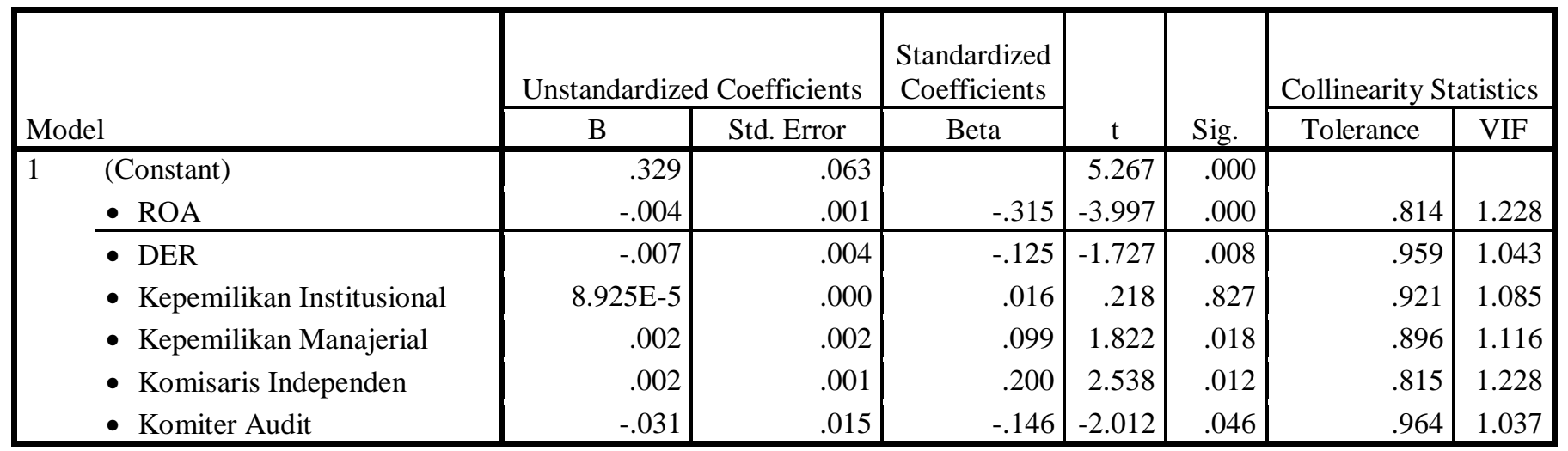

a. Dependent Variable: CETR

Sumber: Data yang diolah (2018)

Melihat hasil besaran korelasi antar variabel pada Tabel 4.3 menunjukkan untuk VIF dan Tolerance mengindikasikan tidak terdapat multikolinearitas yang serius. Nilai VIF tidak ada yang melebihi 10 dan nilai Tolerance tidak ada yang kurang dari 0,10. Maka dapat dikatan tidak terjadi multikolinearitas yang serius dalam model regresi penelitian.

\section{Uji Autokorelasi}

Dalam penelitian ini untuk mendeteksi ada atau tidaknya autokorelasi yaitu dengan melakukan run test. Run test digunakan sebagai bagian dari statistik non-parametik yang dapat juga digunakan untuk menguji apakah antar residual terdapat korelasi yang tinggi. Jika antar residual tidak terdapat hubungan korelasi maka dikatakan bahwa residual adalah acak atau random.

Berikut hasil uji autokorelasi yang dapat dilihat dalam tabel 4.4
Tabel 4.4

Hasil Uji Autokorelasi

Runs Test

\begin{tabular}{|l|r|}
\hline & \multicolumn{1}{|c|}{ Unstandardized } \\
& Residual \\
\hline Test Value ${ }^{\mathrm{a}}$ & -.01924 \\
Cases $<$ Test Value & 90 \\
Cases $>=$ Test Value & 90 \\
Total Cases & 180 \\
Number of Runs & 98 \\
$Z$ & 1.046 \\
Asymp. Sig. (2-tailed) & .295 \\
\hline
\end{tabular}

Sumber: Data yang diolah (2018)

Hasil run test menunjukkan bahwa nilai Asymp.Sig. (2-tailed) sebesar $0.295>0.05$ yang berarti data yang dipergunakan cukup random sehingga tidak terdapat masalah autokorelasi pada data yang diuji.

\section{Uji Heteroskedastisitas}

Uji heteroskedastisitas dilakukan untuk menguji apakah model regresi terjadi ketidaksamaan varians dari residual suatu pengamatan ke pengamatan lain. Gambar di bawah ini merupakan hasil uji heteroskedastisitas untuk variabel independen yaitu: profitabilitas, leverage, kepemilikan institusional, 
kepemilikan manajerial, komisaris independen, komite audit terhadap variabel dependen yaitu perencanaan pajak.

Berikut ini adalah hasil uji heteroskedastisitas menggunakan grafik scatterplot.

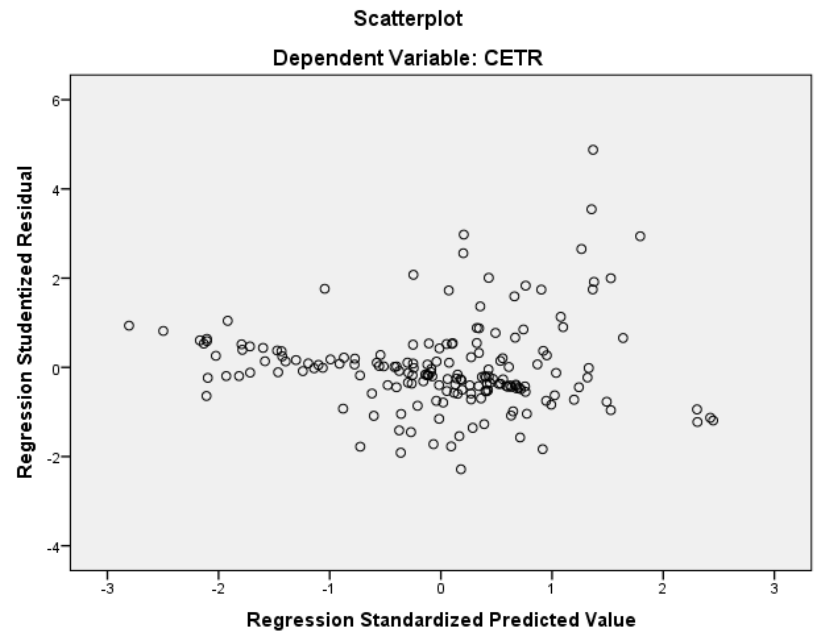

Sumber: Data yang diolah (2018)
Pada gambar 4.3 diatas menunjukkan titik-titik menyebar secara acak dan tidak membentuk suatu pola, baik di atas maupun di bawah angka 0 pada sumbu Y. Hal ini berarti tidak terjadi heteroskedastisitas pada model regresi.Dapat disimpulkan bahwa instrumen penelitian ini memenuhi asumsi heterokedastisitas.

\section{Uji Hipotesis}

\section{Hasil Uji Koefisien Determinasi}

Koefisien determinasi $\left(\mathrm{R}^{2}\right)$ bertujuan untuk mengukur seberapa besar kemampuan model dalam menerangkan variasi variabel independen. Hasil koefisien determinasi dapat dilihat pada tabel 4.5 berikut.

\section{Gambar 4.3 Hasil Uji Heteroskedastisitas}

Tabel 4.5

Hasil Uji Koefisien Determinasi (R2)

Model Summary $^{\text {b }}$

\begin{tabular}{|l|r|r|r|r|r|}
\hline Model & \multicolumn{1}{|c|}{ R } & R Square & \multicolumn{1}{|c|}{ Adjusted R Square } & Std. Error of the Estimate & Durbin-Watson \\
\hline 1 & $.357^{\mathrm{a}}$ & .127 & .097 & .122095 & 2.142 \\
\hline
\end{tabular}

a. Predictors: (Constant), Komiter_Audit, Komisaris_Independen, DER, Kepemilikan_Institusional, Kepemilikan_Manajerial, ROA

b. Dependent Variable: CETR

Sumber : Data yang diolah (2018)

Dari Tabel 4.5 di atas diketahui bahwa nilai Adjusted $R$ Square adalah sebesar 0,122095. Hal ini berarti bahwa sebesar 12,2095\% variabel dependen atau perencanaan pajak dipengaruhi oleh variabel independen yaitu profitabilitas, leverage, kepemilikan institusional, kepemilikan manajerial, komisaris independen, komite audit. Sedangkan sisanya yaitu sebsar $87.7905 \%$ dipengaruhi oleh faktor lain yang tidak digunakan dalam penelitian ini.

\section{Hasil Uji F}

Hasil uji F bertujuan untuk mengetahui apakah seluruh variabel independen secara bersama-sama (simultan) memiliki pengaruh yang signifikan terhadap variabel dependen. Signifikan model regresi pada penelitian ini diuji dengan melihat nilai signifikansi (sig). Hasil uji F pada penelitian ini dapat dilihat pada tabel 4.6 berikut:

\section{Tabel 4.6 \\ Hasil Uji F \\ ANOVA $^{\mathrm{a}}$}

\begin{tabular}{|ll|r|r|r|r|r|}
\hline Model & \multicolumn{1}{|c|}{ Sum of Squares } & Df & Mean Square & \multicolumn{1}{c|}{ F } & Sig. \\
\hline 1 & Regression & .376 & 6 & .063 & 4.207 & $.001^{\mathrm{b}}$ \\
& Residual & 2.579 & 173 & .015 & & \\
& Total & 2.955 & 179 & & & \\
\hline
\end{tabular}

a. Dependent Variable: CETR 
b. Predictors: (Constant), Komiter_Audit, Komisaris_Independen, DER, Kepemilikan_Institusional,

Kepemilikan_Manajerial, ROA

Sumber: Data yang diolah (2018)

Dari Tabel 4.6 di atas menunjukkan bahwa nilai F hitung sebesar 4,207 dengan nilai sig. sebesar 0,001. Hal ini menandakan bahwa model regresi dapat digunakan untuk memprediksi variabel dependen karena nilai sig. <alpha $(\alpha=5 \%)$. Maka dapat disimpulkan bahwa terdapat pengaruh simultan yang signifikan antara profitabilitas, leverage, kepemilikan institusional, kepemilikan manajerial, komisaris independen, komite audit terhadap perencanaan pajak.

\section{Hasil Uji t}

Hasil uji t dapat dilihat dari nilai signifikansi profitabilitas, leverage, kepemilikan institusional, kepemilikan manajerial, komisaris independen, komite audit dalam menerangkan variabel dependen yaitu perencanaan pajak.

Hasil uji $\mathrm{T}$ dapat dilihat pada Tabel 4.7 berikut ini.

Tabel 4.7

Hasil Uji Statistik $\mathbf{t}$

Coefficients $^{\mathrm{a}}$

\begin{tabular}{|c|c|c|c|c|c|c|c|c|}
\hline & & \multicolumn{2}{|c|}{$\begin{array}{l}\text { Unstandardized } \\
\text { Coefficients }\end{array}$} & \multirow{2}{*}{$\begin{array}{r}\text { Standardized } \\
\text { Coefficients } \\
\text { Beta }\end{array}$} & \multirow[b]{2}{*}{$\mathrm{t}$} & \multirow[b]{2}{*}{ Sig. } & \multicolumn{2}{|c|}{ Collinearity Statistics } \\
\hline \multicolumn{2}{|c|}{ Model } & $\mathrm{B}$ & Std. Error & & & & Tolerance & VIF \\
\hline & (Constant) & .329 & .063 & & 5.267 & .000 & & \\
\hline & - $\mathrm{ROA}$ & -.004 & .001 & -.315 & -3.997 & .000 & .814 & 1.228 \\
\hline & - DER & -.007 & .004 & -.125 & -1.727 & .008 & .959 & 1.043 \\
\hline & - Kepemilikan Institusional & $8.925 \mathrm{E}-5$ & .000 & .016 & .218 & .827 & .921 & 1.085 \\
\hline & - Kepemilikan Manajerial & .002 & .002 & .099 & 1.822 & .018 & .896 & 1.116 \\
\hline & - Komisaris Independen & .002 & .001 & .200 & 2.538 & .012 & .815 & 1.228 \\
\hline & - Komiter Audit & -.031 & .015 & -.146 & -2.012 & .046 & .964 & 1.037 \\
\hline
\end{tabular}

a. Dependent Variable: CETR

Sumber : Data yang diolah (2018)

Dari tabel 4.7 di atas, dapat dilihat bahwa koefisien model regresi memiliki nilai konstanta sebesar 0,329 dengan nilai $\mathrm{t}$ hitung sebesar 5,267 dengan nilai sig. sebesar 0,000 . Konstanta sebesar 0,329 menandakan bahwa jika variabel independen konstan maka rata-rata perencanaan pajak adalah sebesar 0,329.

Penarikan kesimpulan untuk pungujian hipotesis yaitu dengan membantingkan antara $t$ tabel dengan $t$ hitung. t tabel untuk df sebesar 38 (jumlah sampel jumlah variabel independen - 1) adalah 1,68595 atau 1,686. Apabila t tabel lebih kecil jika dibandingkan dengan $t$ hitung, maka variabel tersebut berpengaruh terhadap variabel dependen.

\section{Pengujian Hipotesis Pertama (H1)}

Hipotesis pertama dalam penelitian ini adalah profitabilitas berpengaruh positif terhadap perencanaan pajak. Hasil uji $\mathrm{t}$ pada table diatas menunjukkan bahwa nilai $\mathrm{t}$ variabel profitabilitas sebesar -3.997 dengan nilai signifikansi sebesar 0,000. Nilai tersebut menunjukkan bahwa thitung lebih besar dari nilai $t$ tabel dan sig $0,000<\alpha 0,05$, sehingga dapat disimpulkan bahwa hipotesis diterima, profitabilitas berpengaruh secara signifikan terhadap perencanaan pajak.

\section{Pengujian Hipotesis Kedua (H2)}

Hipotesi kedua dalam penelitian ini adalah leverage berpengaruh terhadap perencanaan pajak. Hasil uji t pada table diatas menunjukkan bahwa nilai $\mathrm{t}$ variabel leverage sebesar -1.727 dengan nilai signifikansi sebesar 0,008 . Nilai tersebut menunjukkan bahwa t hitung lebih besar dari nilai t tabel dan sig $0,008<\alpha 0,05$, ini menunjukkan bahwa leverage signifikan terhadap perencanaan pajak. Sehingga dapat disimpulkan bahwa hipotesis diterima. Leverage berpengaruh signifikan terhadap perencanaan pajak. 


\section{Pengujian Hipotesis ketiga (H3)}

Hipotesi ketiga dalam penelitian ini adalah kepemilikan institusional berpengaruh terhadap perencanaan pajak.Hasil uji $\mathrm{t}$ pada table diatas menunjukkan bahwa nilai $\mathrm{t}$ variabel kepemilikan institusional sebesar 0.218 dengan nilai signifikansi sebesar 0,827 . Nilai tersebut menunjukkan bahwa $\mathrm{t}$ hitung lebih kecil dari nilai $\mathrm{t}$ tabel dan sig $0,827>\alpha$ 0,05 , ini menunjukkan bahwa kepemilikan institutional tidak signifikan terhadap perencanaan pajak. Sehingga dapat disimpulkan bahwa hipotesis ditolak, kepemilikan institusional tidak berpengaruh signifikan terhadap perencanaan pajak.

\section{Pengujian Hipotesis Keempat (H4)}

Hipotesi keempat dalam penelitian ini adalah kepemilikan manajerial berpengaruh terhadap perencanaan pajak.Hasil uji $\mathrm{t}$ pada table diatas menunjukkan bahwa nilai $\mathrm{t}$ variabel kepemilikan manjerial sebesar 1.822 dengan nilai signifikansi sebesar 0,018. Nilai tersebut menunjukkan bahwa $t$ hitung lebih besar dari nilai $\mathrm{t}$ tabel dan sig $0,018<\alpha$ 0,05 , ini menunjukkan bahwa kepemilikan manajerial signifikan terhadap perencanaan pajak. Sehingga dapat disimpulkan bahwa hipotesis diterima, kepemilikan manajerial berpengaruh signifikan terhadap perencanaan pajak.

\section{Pengujian Hipotesis Kelima (H5)}

Hipotesi kelima dalam penelitian ini adalah komisaris independen berpengaruh terhadap perencanaan pajak.Hasil uji $\mathrm{t}$ pada tabel diatas menunjukkan bahwa nilai $t$ variabel komisaris independensebesar 2.538 dengan nilai signifikansi sebesar 0,012 . Nilai tersebut menunjukkan bahwa $\mathrm{t}$ hitung lebih besar dari nilai $\mathrm{t}$ tabel dan sig $0,012<\alpha$ 0,05 . Sehingga dapat disimpulkan bahwa hipotesis diterima, komisaris independen berpengaruh signifikan terhadap perencanaan pajak.

\section{Pengujian Hipotesis keenam (H6)}

Hipotesi keenam dalam penelitian ini adalah komite audit berpengaruh terhadap perencanaan pajak. Hasil uji t pada table diatas menunjukkan bahwa nilai $t$ variabel komite audit sebesar 2,012 dengan nilai signifikansi sebesar 0,046. Nilai tersebut menunjukkan bahwa t hitung lebih besar dari nilai t tabel dan sig $0,046<\alpha 0,05$. Sehingga dapat disimpulkan bahwa hipotesis diterima, komite audit berpengaruh signifikan terhadap perencanaan pajak.

\subsection{Kesimpulan}

Berdasarkan pengujian dengan model regresi berganda atas data yang telah dkumpulkan, maka dapat disimpulkan:

1. Profitabilitas berpengaruh signifikan terhadap perencanaan pajak.

2. Leverage berpengaruh signifikan terhadap perencanaan pajak.

3. Kepemilikan institusional tidak berpengaruh signifikan terhadap perencanaan pajak.

4. Kepemilikan manajerial berpengaruh signifikan terhadap perencanaan pajak.

5. Komisaris independen berpengaruh signifikan terhadap perencanaan pajak.

6. Komite audit berpangaruh signifikan terhadap perencanaan pajak.

7. Profitabilitas, leverage, kepemilikan institusional, kepemilikan manajerial, komisaris independen dan komite audit berpengaruh secara simultan terhadap perencanaan pajak.

\subsection{Keterbatasan}

Adapun keterbatasan dalam penelitian ini adalah sebagai berikut.

1. Penelitian ini hanya menggunakan rasio profitabilitas, leverage, kepemilikan institusional, kepemilikan manajerial, komisaris independen dan komite audit sebagai variabel independennya. Masih banyak lagi faktor yang dapat mempengaruhi perencanaan pajak yang dilakukan oleh perusahaan seperti ukuran prusahaan, sales growth dan capital intensity.

2. Penelitian ini hanya menggunakan salah satu proksi penelitian untuk rasio profitabilitas dan leverage. Masih terdapat beberapa proksi lain yang mewakili penilaian rasio ini.

\subsection{Saran}

1. Untuk penelitian selanjutnya, variabel dan periode penelitian agar dapat ditambahkan sehingga variabel dan periode dalam penelitian selanjutnya dapat memberikan sampel yang lebih banyak serta hasil yang akurat.

2. Objek penelitian yang digunakan sebagai sampel penelitian agar ditambah menjadi seluruh 
perusahaan yang terdaftar di BEI sehingga hasil penelitian dapat digenaralisasi dan lebih menjelaskan variabilitas data yang sesungguhnya.

3. Dapat menambah atau mengganti proksi perhitungan dalam rasio profitabilitas ataupun leverage. Contohnya pada rasioprofitabilitas dapat menggunakan ROE dan pada rasio leverage dapat menggunakan long term debt to equity ratio.

Metode pengukuran perencanaan pajaknya dapat menggunakan model lain seperti GAAP ETR.

\section{Daftar Pustaka}

Aditama, Ferry \& Anna Purwaningsih. 2013. Pengaruh Perencanan Pajak Terhadap Manajemen Laba pada Perusahaan Manufaktur yang terdaftar di Bursa Efek Indonesia. Jurnal Ilmiah. Yogyakarta: Universitas Atma Jaya Yogyakarta. Agusti. Wirna Yola. 2014. Pengaruh Profitabilitas, Leverage dan Corporate Governance Terhadap Tax Avoidance. UNP, Padang.

Agustiani, Priska W. 2013. Pengaruh Good Corporate Governance Terhadap Nilai Perusahaan. EJournal Akuntansi Vol 2. No 2 . Rokan Hulu: Fakultas Ekonomi Universitas Pasir Pengaraian.

Andani , Bella Cucu Putri \&Burhanudin. 2015. Analisis Tax Planning Melalui Deductible Expenses dan Perbandingan Metode Penyusutan Aktiva Tetap Berdasarkan Komersial Dan Fiskal Atas Pajak Penghasilan. Jurnal Akuntansi. Vol 2 No. 1 Juli 2015. Serang Jaya: Universitas Serang Jaya.

Anissa, Nuralifmida Ayu \& Lulus Kurniasih. 2012. Pengaruh Corporate Governance Terhadap Tax Avoidanc. Jurnal Akuntansi \& Auditing.Vol.8. NO.2 . pp.95-189.

Arianandini, Putu Winning dan I Wayan Ramantha. 2018. Pengaruh Profitabilitas, Leverage, dan Kepemilikan Institusional pada Tax Avoidance. E-Jurnal Akuntansi. Bali: Fakultas Ekonomi dan Bisnis Universitas Udayana (UNUD).

Arikunto, S. 2010. Prosedur Penelitian: Suatu Pendekatan Praktik. Jakarta: Rineka Cipta.

Armstrong, Christopher S, Jennifer L. Blouin, Alan D. Jagolinzer. 2015. Corporate governance, incentives, and tax avoidance. Journal of Accounting and Economic.

BAPEPAM, (2014), Surat Keputusan Direksi PT. Bursa Efek Indonesia. Perubahan Peraturan
No.1-A tentang Pencatatan Saham dan Efek Bersifat Ekuitas Selain Saham.

Bina Jasa Konsultan Pajak, 2012. Strategi Umum Perencanaan Pajak.

Darmawan, I Gede Hendy \& I Made Sukartha. 2014. Pengaruh Penerapan Corporate Governance, Leverage, Return On Assets, Dan Ukuran Perusahaan Pada Penghindaran Pajak. E-Journal Akuntansi Universitas Udayana.

Dyreng, et al., 2010. The Effect of Executives on Corporate Tax Avoidance. The Accounting Review, 85, 1163-1189.

Effendi, Muh Arief. 2009. The Power Of Corporate Governance. Jakarta: Salemba Empat.

Fahmi, Irham. 2010. Manajemen Kinerja. Bandung: Alfabet.

Fatharani, Nazhaira. 2012. Pengaruh Karaketeristik Kepemilikan, Reformasi Perpajakan, dan Hubungan Politik Terhadap Tindakan Pajak Agresif. Skripsi. Fakultas Ekonomi Program Studi Akuntansi Universitas Indonesia.

FCGI. 2001. Corporate Governance: Tata Kelola Perusahaan, Edisi ketiga. Jakarta

Ghozali, Imam. 2001. Aplikasi Analisis Multivariate Dengan Program SPSS. Edisi Kedua. Semarang. Hanafi, M. Mamduh \& Abdul Halim. 2009. Analisis Laporan Keuangan. Yogyakarta: UPP AMP YKPN.

Harahap, Sofyan Syafri. 2004. Analisis Kritis Atas Laporan Keuangan. Jakarta: Raja Grafindo Persada.

Hartadinata, Okta S. \& Heru Tjakara. 2013. Analisis Pengaruh Kepemilikan Manajerial, Kebijkan Utang, dan Ukuran Perusahaan terhadap Tax Aggressiveness. Jurnal Ekonomi Dan Bisnis.

http://membunuhindonesia.net/2015/10/kejahatankeuangan-di-sektor-pertambangan/.

https://ekonomi.kompas.com.

https://finance.detik.com/berita-ekonomi-bisnis/d-

3340810/soal-pajak-google-sri-mulyani-darisisi-moralitas-tidak-bisa-diterima.

https://www.liputan6.com/bisnis/read/2626083/memb ongkar-strategi-penghindaran-pajak-google-didunia.

Ifanda, B.A. 2016. Analisis Pengaruh Profitabilitas, Leverage, dan kompensasi Rugi Fiskal Terhadap Tax Avoidance. Journal Accounting. 
Bandar Lampung: Fakultas Ekonomi dan Bisnis Universitas Lampung.

Ismiati, Fitri dan M. Hanafi Mamduh. 2004. Struktur Kepemilikan, Risiko, dan Kebijakan Keuangan: Analisis Persamaan Simultan. Jurnal Ekonomi dan Bisnis Indonesia Vol.19, No.2.

Jensen, M., and Meckling W. 1986. Theory of The Firm: Manajerial Behavior Agency Cost, and Ownership Structur. Journal of Financial Economic.

Kasmir. 2014. Dasar-dasar Perbankan Edisi Revisi. Jakarta: PT Raja Grafindo.

Khaoula, Aliani. 2013. Does Corporate Governance affect tax planning? Evidence from American companies. International Journal of Advanced Research . Volume 1, Issue 10, 864-873. ISSN 2320-5407.

Komite Nasional Kebijakan Governance (KNKG). 2006.Pedoman Umum Good Corporate Governance Indonesia. Indonesia: KNKG.

Kurniasih, Tommy, Maria M.R.S. 2013. Pengaruh Return On Asset (ROA), leverage, corporate Governance, Ukuran Perusahaan dan Kompensasi Rugi Fiskal pada tax avoidance. Buletin Studi Ekonomi. Bali: Fakultas Ekonomi dan Bisnis Universita Udayana.

Liviani, shiela, Putu A.M., Liliana I.W. 2016. Uji Model Keseimbangan Teori Keagenan: Pengaruh Kebijakan Utang dan Kebijakan Deviden terhadap Kepemilikan Manajerial. DeReMa Jurnal Manajemen Vol. 11 No. 1. Surabaya: Universitas Surabaya.

Maharani, I.G.A \& Suardana, K.A. 2014. Pengaruh Corporate Governance, Profitabilitas, dan Karakteristik Eksekutif pada Tax Avoidance. Ejurnal Akuntansi.

Maria, M. \& Nur C. 2013. Pengaruh Corporate Governance terhadap Manajemen Pajak. Diponegoro Journal Accounting. ISSN: i23373806 Volume 2 No.2.

Munawir. 2010. Analisa Laporan Keuangan. Yogyakarta: Liberty.

Oktofian, Muhammad. 2015. Pengaruh Corporate Governance terhadap Tax Avoidance. Universitas Islam Negeri Syarif Hidayatullah, Jakarta.

Oyeyemi, Ogundajo Grace dan Onakoya A. B. 2016. Tax Planning And Financial Performance Of
Nigerian Manufacturing Companies. Journal Of Accounting And Taxation. ISSN : 24889849.

Permanasari, Wien Ika. 2010. Pengaruh Kepemilikan Manajemen, Kepemilikan Institusional dan Corporate Resposibility Terhadap Nilai Perusahaan. Semarang: Universitas Diponegoro.

Pohan, C.A. 2013. Manajemen Perpajakan. Jakarta: Gramedia.

Prakosa, K. B. 2014. Pengaruh Profitabilitas, Kepemilikan Keluarga, dan Corporate Governance terhadap Penghindaran Pajak di Indonesia. Simposium Nasional Akuntansi XVII. Mataram.

Purwaningtyas, Frysa P. 2011. Analisis Pengaruh Mekanisme Good Corporate Governance Terhadap Nilai Perusahaan. Semarang: Universitas Diponegoro.

Puspita, Silvia Ratih dan Puji Harto. 2014. Pengaruh Tata Kelola Perusahaan terhadap Penghindaran Pajak. Diponegoro Journal of Accounting: 2337-3806 Volume 3 No.2.

Rachmawati, Andri dan Hanung Triatmoko, 2007. Analisis Faktor-Faktor Yang Mempengaruhi Kualitas Laba dan nilai Perusahaan. Simposium Nasional Akuntansi X.

Richardson dan Roman Lanis. 2007. Determinants of the Variability in Corporate Effective Tax Rates and Tax Reform. Jurnal Akuntansi.

Rinaldi dan Cheiseiviyanny Cahroline. 2015. Pengaruh Profitabilitas, Ukuran Perusahaan dan Kompensasi Rugi Fisal terhadap Tax Avoidance.Universitas Negri Padang.

Rori, Handri. 2013. Analisis Penerapan Tax Planning Atas Pajak Penghasilan Badan. Jurnal Riset Ekonomi, Manajemen, Bisnis dan Akuntansi. Manado: Fakultas Ekonomi Universitas Sam Ratulangi Manado.

Sabila, Nisa. 2012. Pengaruh Kualitas Corporate Governance Terhadap Kinerja Perusahaan perserta Corporate Governance Perception Index (CGPI). Artikel Ilmiah.

Santoso, Budi. 2015. Keagenan (Agency) PrinsipPrinsip Dasar, Teori, dan Problematika Hukum Keagenan Seri Hukum Bisnis. Jakarta: Ghalia Indonesia.

Saputra, M.D.R dan Nur Fajriah A. 2017. Pengaruh Profitabilitas, Leverage Dan Corporate 
Governance Terhadap Tax Avoidance. Jurnal Ilmu dan Riset Akuntansi. Surabaya: Sekolah TinGgi Ilmu Ekonomi Indonesia Surabaya (STIEA).

Sari, G. M. 2014. Pengaruh Corporate Governace, Ukuran Perusahan, Kompensasi Rugi Fiskal dan Struktur Kepemilikan Terhadap Tax Avoidance. Jurnal Akuntansi. Padang: Universitas Negeri Padang.

Sekaran, Uma dan Bougie, Roger. 2013. Research Methods for Business. United Kingdom: Jhon Wiley \& Sons Ltd.

Suandy, Erly. 2008. Perencanaan Pajak. Edisi 3. Jakarta: Salemba Empat.

Subagiastra, Komang, I Putu Edy Arizona, dan I Nyoman Kusuma Adnyana Mahaputra. 2016. Pengaruh profitabilitas, kepemilikan keluarga, dan good corporate governance terhadap penghindaran pajak. Jurnal Ilmiah Akuntansi. Denpasar : Universitas Mahasarawati.

Sugiyono. 2012. Memahami Penelitian Kualitatif. Bandung: Alfabeta.

Sulistiani, Marchia. 2013. Analisis Pengaruh Struktur Kepemilikan, Devident Payment Ratio, Cash Holding dan Kualitas Audit Terhadap Nilai Perusahaan. Jakarta: Fakultas Ekonomi dan Bisnis Universitas Islam Negeri Syarif Hidayatullah.

Swingly, C. dan I Made Sukartha. 2015. Pengaruh Karakter Eksekutif, Komite Audit, Ukuran Perusahaan, Laverage dan Sales Growth pada Tax Avoidance. E-Jurnal Akuntansi. Bali: Fakultas Ekonomi dan Bisnis Universita Udayana.

Taufik, B.D. \& Yulius J. Christiawan. 2017. Pengaruh Penerapan Corporate Governance terhadap Kinerja Keuangan Perusahaan dengan Ukuran Perusahaan dan Current Ratio sebagai Variabel Kontrol. Jurnal. Surabaya: Fakultas Akuntansi Bisnis Universitas Kristen Petra.

The Institute Indonesia of Corporate Governanc (IICG). 2006. Jakarta.

Undang-undang Republik Indonesia nomor 28 tahun 2007 Pasal 1 ayat 1. Ketentuan Umum dan Tata Cara Perpajakan.

Utami, N.W. 2013. Pengaruh Struktur Corporate Governance, Size, Profitabilitas Perusahaan terhadap Tax Avoidance. Jurnal. Surabaya: Universita Negeri Subayrabaya.

www.beritasatu.com/eropa/387930-bukan-hanya-diindonesia-google-juga-hindari-pajak-dieropa.html.

Ylonen, Matti \& Matias Laine. 2014. A case study of tax planning and corporate social responsibility reporting. Critical Perspectives On Accounting.

Zain, Mohammad. 2008. Manajemen Perpajakan. Edisi 3. Jakarta: Salemba Empat.

Zamhuri, Qamaruz. 2016. Pengaruh Corporate Governancen, Ukuran Perusahan, Kompensasi Rugi Fiskla, dan Stuktur Kepemilikan terhadap Tax Avoidance. Jurnal. Yogyakarta: Universitas Muhammadiyah Yogyakarta. 